\title{
Wybrane aspekty realizacji zadań rozwojowych a procesy tożsamościowe u kobiet we wczesnej dorosłości
}

\section{Selected Aspects of Fulfilling Developmental Tasks and Identity Formation among Young Women}

\begin{abstract}
The present study investigated the relations between selected aspects of two developmental tasks typical of early adulthood (Marriage/Partner relationships and Work) and identity formation. The issue appears to be relevant as a postponement of developmental tasks realization as well as a lengthening of the time of identity formation can be observed. The sample included 151 women at the age of 22-30. The relation was measured with the use of two questionnaires: the Developmental Tasks Scale by A. Oleszkowicz, A. Misztela and Questionnaire of Identity Formation by A. Oleszkowicz, A Słowińska (referring to the Dual-Cycle Model of Identity Formation by Luyckx et al., 2006). The results show that a higher level of preparation for doing the investigated developmental tasks and a higher satisfaction resulting from the stage and way of their realization are connected with a higher identification with commitment. The opposite relation refers to ruminative exploration and exploration in breadth. Moreover, we observe more relations between the investigated aspects of developmental tasks and identification with commitment in the case of Marriage/Partner relationships than in the case of Work. On the basis of the results of the study, one can conclude that a greater involvement in doing developmental tasks typical of early adulthood is to a higher degree accompanied with a willingness to take responsibility for a long-term commitment, and to a lower degree with a need to seek for new solutions, as well as anxiety and uncertainty connected with exploration processes.
\end{abstract}

Keywords: early adulthood, developmental tasks, marriage/partner relationships, work, identity formation.

Słowa kluczowe: wczesna dorosłość, zadania rozwojowe, związki małżeńskie/partnerskie, praca zawodowa, procesy tożsamościowe.

\section{WPROWADZENIE}

W literaturze przedmiotu przyjmuje się, że okres wczesnej dorosłości przypada pomiędzy 20./22. a 35./40. rokiem życia człowieka
(Brzezińska, Appelt, Ziółkowska, 2008; Gurba, 2011). W tym czasie jednostka osiąga pełnię sił fizycznych, szczytową sprawność intelektualną oraz dojrzałość psychospołeczną, co pozwala jej na samodzielne podejmowanie i odpowie- 
dzialne wypełnianie obowiązków związanych z realizacją nowych ról społecznych (zadań rozwojowych). Jednak od około 30 lat (szczególnie w kulturze zachodniej) obserwujemy wyraźnie pogłębiającą się tendencję do odraczania realizacji zadań rozwojowych okresu wczesnej dorosłości i indywidualizację ich przebiegu. Dlatego też wielu badaczy, w tym psychologowie rozwojowi, podejmuje się analizy tego zjawiska, a także poszukiwania zarówno psychicznych uwarunkowań, jak i konsekwencji omawianego trendu. Jednym z czynników psychologicznych pozostających w relacji z podejmowanymi zadaniami rozwojowymi jest kształtująca się tożsamość jednostki. Jej dojrzała forma oznacza podejmowanie trwałych zobowiązań, co nie jest bez znaczenia dla zadań i ról społecznych ważnych w okresie dorosłości.

Celem podjętych badań było zatem poznanie związków pomiędzy wybranymi aspektami realizacji zadań rozwojowych a stopniem nasilenia procesów tożsamościowych leżących u podstaw formującej się tożsamości. Badanie w całości obejmowało grupę kobiet we wczesnej dorosłości. Przedstawiona analiza wyników obejmuje dwa zadania rozwojowe: zawarcie zwiazku matzeńskiego/wybór partnera i podjęcie pracy zawodowej. Za podstawę teoretyczną procesów formowania się tożsamości przyjęto zmodyfikowany przez Aleksandrę Słowińską i Annę Oleszkowicz model Podwójnego Cyklu Formowania się Tożsamości Koena Luyckxa i współpracowników (Luyckx, Goossens, Soenens, 2006; Słowińska, Oleszkowicz, 2016).

\section{ZADANIA ROZWOJOWE WE WCZESNEJ DOROSŁOŚCI}

Periodyzacja rozwoju człowieka wyznaczana jest według różnych kryteriów. Jednym z nich są zadania rozwojowe, rozumiane jako typowe dla danego okresu życia problemy, które jednostka powinna podjąć i rozwiązać (Havighurst, 1972). W okresie wczesnej dorosłości wskazuje się na następujące zadania: wybór małżonka, uczenie się współżycia z nim, założenie rodziny, wychowywanie dziecka, prowadzenie domu, rozpoczęcie pracy zawo- dowej, podjęcie obowiązków obywatelskich oraz znalezienie pokrewnej grupy społecznej. Zdaniem Roberta J. Havighursta pomyślna realizacja każdego z tych zadań prowadzi do poczucia zadowolenia oraz sprzyja sukcesowi w podejmowaniu zadań rozwojowych charakterystycznych dla kolejnych okresów życia. Co więcej, rezultat ten jest istotny nie tylko z punktu widzenia indywidualnych interesów jednostki, lecz także z punktu widzenia interesów społecznych. Na przykład, aktywność zawodowa obywateli zwiększa wpływy podatkowe państwa, z kolei zaangażowanie w funkcjonowanie tzw. trzeciego sektora czy aktywność wyborcza młodych ludzi może się przyczynić do zmiany władzy czy rozwoju idei społeczeństwa obywatelskiego. Choć koncepcja zadań rozwojowych Havighursta zasadniczo wydaje się mieć charakter uniwersalny, to jednak okazuje się, że tempo i sposób realizacji zadań rozwojowych w znacznym stopniu zależą od uwarunkowań kulturowych. Współcześnie odchodzi się od jednego, obowiązującego modelu wyznaczającego czas, tempo czy kolejność podejmowania zadań rozwojowych. Ścieżki rozwoju cechują się znacznym zindywidualizowaniem, mówi się o ich nienormatywnym charakterze i zmianie znaczenia tego, co do tej pory oznaczało punktualność podejmowania nowych ról społecznych (Brzezińska, Kaczan, Piotrowski i Rękosiewicz, 2011).

Trendy, o których mowa, znajdują swoje potwierdzenie w danych statystycznych. W 1990 roku w Polsce przeciętny wiek wkraczania kobiet w związek małżeński to 23 lata, podczas gdy w roku 2015 to 27 lat (GUS, 2016). W 2015 roku mężczyzna zawierający związek małżeński miał średnio 29 lat, czyli o ponad 4 lata więcej niż na początku lat 90 . XX wieku (GUS, 2016). W ślad za tym opóźnia się także moment podjęcia ról rodzicielskich. Średni wiek urodzenia pierwszego dziecka w Polsce przesunął się z 23. roku życia w roku 1990, na 29. rok życia w roku 2015 (GUS, 2016). Podobnie wygląda kwestia zamieszkania poza domem rodzinnym, a więc podjęcia zadania, jakim jest samodzielne prowadzenie gospodarstwa domowego. W 2014 roku statystyczna Polka opuszczała dom rodzinny w wieku 27 lat, statystyczny Polak zaś 
w wieku 29 lat (Eurostat, 2015, za: Sikorska, 2015). W grupie polskich 18-24-latków 81\% kobiet i $89 \%$ mężczyzn mieszka w domu rodzinnym, natomiast w grupie 25-34-latków $30 \%$ kobiet i 44\% mężczyzn nadal mieszka $\mathrm{z}$ rodzicami. W całej grupie 18-34-latków jedynie $49 \%$ kobiet i 37\% mężczyzn prowadzi gospodarstwo domowe samodzielnie lub wraz z partnerem (Eurostat, 2011, za: Turek, 2013). Inaczej kształtuje się sytuacja w zakresie aktywności zawodowej młodych ludzi. Od 2000 do 2010 roku średni wiek wkraczania kobiet na rynek pracy przesunął się o rok, z 22. na 23. rok życia. W tym samym czasie w przypadku mężczyzn wiek ten pozostał bez zmian i jest to nadal przeciętnie 22. rok życia (Boni, 2011).

Poszukiwanie przyczyn związanych z odraczaniem realizacji zadań rozwojowych koncentruje się w głównej mierze na czynnikach kulturowych. Niewatpliwie przełomową propozycją stała się koncepcja stajacej się dorosłości (emerging adulthood), amerykańskiego badacza Jeffreya J. Arnetta (2000, 2004), który mówi o nowym okresie rozwojowym przypadającym na czas pomiędzy późną adolescencją a wczesną dorosłością, czyli pomiędzy 18. a 25. rokiem życia. Według Arnetta do cech dystynktywnych stającej się dorosłości należą: poszukiwanie tożsamości (eksperymentowanie), poczucie wielu możliwości, brak stabilności, poczucie ,bycia pomiędzy” i zainteresowanie sobą (por. też Zagórska, Jelińska, Surma, Lipska, 2012). Cechy te pozostają w znaczącej współzależności z etapem realizacji różnych zadań rozwojowych. Na przykład, osoby pracujące dorywczo charakteryzują się znacznie silniejszym poczuciem braku stabilności niż pracujące w pełnym wymiarze godzin; osoby samotne widzą przed sobą wiele możliwości, a także znacznie bardziej koncentrują się na sobie $\mathrm{w}$ porównaniu $\mathrm{z}$ osobami zamężnymi (żonatymi). Z kolei osoby mieszkające z rodziną pochodzenia bardziej czują się ,pomiędzy” i mniej stabilnie w porównaniu $\mathrm{z}$ tymi, które mieszkają same lub z partnerem, np. z chłopakiem lub narzeczoną (Oleszkowicz, Misztela, 2015). Dane te wskazują na znaczenie podejmowania nowych ról społecznych (zadań rozwojowych) dla osiągania stabilizacji i doj- rzałości psychospołecznej. Nie dziwi zatem fakt, że coraz częściej podejmowane są badania rozpatrujące tematykę zadań rozwojowych w kontekście ich psychologicznych uwarunkowań, np. osobowościowych (Malina, 2014), ich związku z poczuciem dorosłości czy w końcu z kształtującą się tożsamością jednostki (np. Luyckx, Schwartz, Goossens, Pollock, 2008a; Piotrowski, 2013).

\section{FORMOWANIE SIĘ TOŻSAMOŚCI A PODEJMOWANIE ZADAŃ ROZWOJOWYCH}

Rezultaty badań nad formowaniem tożsamości u osiemnastoletniej młodzieży, prowadzone w latach 1989-2002, pokazują wyraźne zwiększenie liczby młodych ludzi pozostających w moratorium: z 9.4\% w 1989 roku do $21 \% \mathrm{w}$ roku 2002 oraz na etapie tożsamości dyfuzyjnej: z 4.5\% w 1989 roku do $16 \%$ w 2002 roku (Liberska, 2007, por. też Oleś, 2010). Co ciekawe, badania Marii Oleś (2010) przeprowadzone wśród uczniów szkół ponadgimnazjalnych pokazały, że najwyższy poziom jakości życia mają osoby o profilu tożsamości lustrzanej i moratoryjnej, relatywnie niższy zaś młodzież z tożsamością osiągniętą. Współcześnie wiele badań wskazuje na przedłużony proces kształtowania się tożsamości i możliwość jej wielokrotnej weryfikacji (Luyckx, Goossens, Soenens, 2006, Słowińska, Oleszkowicz, 2015, 2016), a także na nierównomierne tempo rozwoju w poszczególnych sferach życia, np. szybciej w sferze zawodowej, a wolniej w ideologicznej (Sugimura, Mizokami, 2012).

W badaniu związków między realizacją zadań rozwojowych a formowaniem się tożsamości osobowej obecnie często wykorzystuje się Model Podwójnego Cyklu Formowania się Tożsamości (Luyckx, Goossens, Soenens, 2006). U podstaw tego modelu leży założenie, że zarówno eksploracja, jak i zobowiązanie (zaangażowanie) to dwa bardziej złożone, dynamiczne i nawzajem przenikające się procesy, niż to początkowo przyjmował James E. Marcia (1966, 1980). Na pierwszy cykl - formowanie zobowiązania - składają 
się procesy eksploracji wszerz (exploration in breadth) i podjęcie decyzji o wstępnym zaangażowaniu się w ważne dla jednostki sfery funkcjonowania (commitment making). Cykl ten oznacza początek procesu kształtowania tożsamości i może zachodzić już we wczesnej adolescencji. Początkowo jednostka poszukuje wśród wielu rozwiązań tych, które jest w stanie uznać za względnie dopasowane do jej indywidualnych potrzeb i możliwości. Następnie podejmuje wstępne zobowiązania co do realizacji owych rozwiązań po to, by w toku eksploracji głębokiej (exploration in depth) (cykl drugi) zostały one bardziej wnikliwie rozpoznane. Zatem drugi cykl - ewaluacja zobowiązania - składa się z eksploracji w głąb (analizy informacji dotyczących wybranych alternatyw i pogłębionej oceny podjętych zobowiązań w celu określenia stopnia ich zgodności z osobistymi standardami, celami i możliwościami), po której następuje podjęcie ostatecznej decyzji o przyjęciu na siebie długoterminowego zobowiązania do jego realizacji (identification with commitment) lub decyzja o ostatecznym jego odrzuceniu i powrocie nawet do fazy eksploracji wszerz. Wziąwszy pod uwagę, że proces formowania tożsamości dotyczy różnych dziedzin życia człowieka: relacji intymnych, aktywności zawodowej, życia towarzyskiego, aktywności obywatelskiej i innych, a także fakt, że poszukiwania te mogą mieć zarówno charakter poznawczy, gdy jednostka na poziomie umysłowym analizuje zasadność danych rozwiązań, jak i behawioralny, gdy podejmuje różne działania zmierzające do przetestowania danych rozwiązań, oczywiste staje się, że proces kształtowania tożsamości jest niezwykle złożony, dynamiczny i rozciągnięty w czasie. Dodatkowo Luyckx i współpracownicy (2008b) poszerzyli opisany powyżej model o piąty proces, eksplorację ruminacyjną (ruminative exploration). Proces ten, w przeciwieństwie do poprzednich, ma charakter nieadaptacyjny. Polega bowiem na uporczywym zaabsorbowaniu poszukiwaniem informacji i rozpatrywaniu różnych alternatyw tożsamościowych w powiązaniu z poczuciem niepewności, intruzywnymi myślami oraz doświadczaniem niepokoju i/lub obniżonego nastroju.
Badania pokazują, że procesy eksploracji wszerz i w głąb wchodzą w bezpośredni ujemny związek z liczbą podejmowanych zadań rozwojowych. Im mniej zadań rozwojowych podejmuje jednostka, tym bardziej są u niej nasilone oba procesy eksploracji. Z kolei wpływ liczby podejmowanych zadań rozwojowych na procesy eksploracji ruminacyjnej i identyfikacji ze zobowiązaniem jest zapośredniczony przez takie czynniki, jak: dojrzałość psychospołeczna i subiektywne poczucie dorosłości. Zatem w uzyskanym modelu podejmowanie zadań rozwojowych leży u podstaw najbardziej zaawansowanego procesu kształtowania się tożsamości - identyfikacji ze zobowiązaniem (Piotrowski, 2013).

Istnieją także dowody wskazujące na mniejsze nasilenie procesu eksploracji u młodych dorosłych aktywnych zawodowo (Danielsen, Lorem, Kroger, 2000; Luyckx i in., 2008a; Piotrowski, Brzezińska, 2011). Zrozumiałe wydaje się, że osoby aktywne zawodowo nie mają tak wiele czasu na poszukiwanie nowych rozwiązań czy analizowanie różnorodnych alternatyw jak osoby niepracujące. Zdaniem Konrada Piotrowskiego (2013) redukowanie aktywności eksploracyjnej wśród osób rozpoczynających pracę zawodową wiąże się z trudną sytuacją w sektorze zatrudnienia. Młodzi ludzie konfrontowani ze współczesnymi wymaganiami rynku pracy angażują dużą ilość energii w podjęte zadanie, dążąc przede wszystkim do utrzymania status $q u o$, a nie do poszerzania czy urozmaicania własnej aktywności zawodowej.

\section{PROBLEM BADAWCZY I HIPOTEZY}

Badania poświęcone związkom między zadaniami rozwojowymi a tożsamością biorą głównie pod uwagę fakt podjęcia (lub nie) tych pierwszych. W badaniach własnych uwzględniłyśmy znacznie więcej aspektów realizacji zadań rozwojowych: etap realizacji zadania, spostrzegany stopień przygotowania do jego pełnej realizacji, ocenę ważności, ocenę tempa realizacji względem grupy rówieśniczej, spostrzeganą motywację wewnętrzną vs zewnętrzną leżącą u jego podstaw oraz zadowo- 
lenie z tempa i sposobu realizacji. Dzięki temu możliwe było oddzielne, wielostronne przeanalizowanie związków między wybranymi zadaniami a procesami tożsamościowymi. Należy zaznaczyć, że wybrane przez nas zadania rozwojowe: zawarcie związku małżeńskiego i podjęcie pracy, przebiegają w różnym tempie i czasie. Podjęcie stałej pracy występuje znacznie wcześniej w okresie dorosłości niż zawarcie związku małżeńskiego. Ponadto dla zadania rozwojowego ,zawarcie związku małżeńskiego" stworzono alternatywę w postaci zadania „wybór stałego partnera”, rozumianego jako pozostawanie w długotrwałym, nieformalnym związku kohabitacyjnym. Decyzja taka została podyktowana doświadczeniami wyniesionymi z rozmów z osobami badanymi podczas wcześniejszych badań dotyczących owej tematyki. Pokazały one, że część młodych ludzi pozostających w związkach kohabitacyjnych traktuje je jako równowartościową alternatywę dla małżeństwa i chociaż nie deklarują oni obecności we własnych planach życiowych chęci zawarcia związku małżeńskiego, to pragną budować długotrwały związek intymny (również posiadać dzieci) z drugą osobą. Chodziło więc o to, aby osoby te miały szansę opisać i ocenić swoją relację $\mathrm{z}$ partnerem $\mathrm{w}$ taki sam sposób, jak osoby żyjące w związkach formalnych. W swoich rozważaniach tacy badacze, jak Piotr Oleś (2011) czy Tomasz Szlendak (2010), również zwracają uwagę na nieuchronność zmian związanych ze sposobem życia młodych ludzi, w którym związki kohabitacyjne stają się nie tylko etapem poprzedzającym zawarcie związku małżeńskiego, lecz także alternatywną formą funkcjonowania $\mathrm{w}$ relacji z partnerem. Także Piotrowski (2013) w swoich badaniach dotyczących podejmowania ról społecznych we wczesnej dorosłości i procesu formowania tożsamości mówi o tworzeniu bliskiego związku i traktuje jako realizujących tę rolę społeczną (małżonka, towarzyszki życia) zarówno badanych pozostających w związkach małżeńskich, jak i partnerskich.

Postawione pytanie badawcze brzmiało: Jakiego rodzaju związki zachodzą między poszczególnymi aspektami realizacji zadań rozwojowych, podejmowanych przez kobiety w okresie wczesnej dorosłości, a procesami kształtowania się ich tożsamości?

Poniżej przedstawiamy szczegółowe hipotezy.

\section{HIPOTEZY BADAWCZE}

H1. Kobiety bardziej zaawansowane w realizacji zadania rozwojowego charakteryzują się większym nasileniem procesów podejmowania zaangażowania i identyfikacji ze zobowiązaniem oraz mniejszym nasileniem refleksyjnego poszukiwania szerokiego i poszukiwania ruminacyjnego niż kobiety mniej zaawansowane.

H2. Kobiety wyżej oceniające swoje przygotowanie do pełnego podjęcia zadania rozwojowego (np. zawarcie małżeństwa, podjęcie stałej pracy zgodnej z aspiracjami zawodowymi) charakteryzują się większym nasileniem procesów podejmowania zaangażowania i identyfikacji ze zobowiązaniem oraz mniejszym nasileniem refleksyjnego poszukiwania szerokiego i poszukiwania ruminacyjnego niż kobiety oceniające swoje przygotowanie jako niższe.

H3. Kobiety oceniające zadanie rozwojowe jako ważniejsze charakteryzują się większym nasileniem identyfikacji ze zobowiązaniem, a mniejszym nasileniem refleksyjnego poszukiwania szerokiego oraz poszukiwania ruminacyjnego.

H4. Kobiety oceniające własne tempo realizacji poszczególnych zadań rozwojowych jako szybsze od większości rówieśników charakteryzują się większym nasileniem identyfikacji ze zobowiązaniem, a mniejszym nasileniem refleksyjnego poszukiwania szerokiego i poszukiwania ruminacyjnego niż kobiety oceniające własne tempo realizacji poszczególnych zadań rozwojowych jako wolniejsze od większości rówieśników.

H5. Kobiety charakteryzujące się wyższą motywacją autonomiczną do realizacji poszczególnych zadań rozwojowych charakteryzują się większym nasileniem identyfikacji ze zobowiązaniem, a mniejszym nasileniem refleksyjnej eksploracji szerokiej oraz procesów eksploracji ruminacyjnej. 
H6. Kobiety bardziej zadowolone ze sposobu i tempa realizacji poszczególnych zadań rozwojowych silniej identyfikują się ze zobowiązaniem oraz słabiej refleksyjnie poszukują wszerz i słabiej poszukują ruminacyjnie niż kobiety mniej zadowolone.

Taka treść hipotez wynika z uogólnionego przewidywania opartego na przeprowadzonych do tej pory badaniach, które wskazuja na dodatnie związki między podejmowaniem zadań rozwojowych a nasileniem procesów identyfikacji ze zobowiązaniem oraz ujemne związki między eksploracją wszerz i eksploracją ruminacyjną (Danielsen, Lorem, Kroger, 2000; Luyckx i in. 2008a; Piotrowski 2013).

\section{OSOBY BADANE}

W badaniu przeprowadzonym w 2014 roku wzięło udział 151 kobiet, w wieku od 22 do 30 lat, studentek wrocławskich i wałbrzyskich uczelni, kierunków pedagogika, politologia, finanse i rachunkowość. Grupa nie była dobierana losowo, lecz na zasadzie dostępności. Badanie miało charakter grupowy. W zakresie pracy zarobkowej najliczniejszą grupę stanowiły badane pracujące na stałe, w pełnym wymiarze godzin (53\%), wyraźnie mniejsza grupę stanowiły pracujące dorywczo (21\%) oraz pracujące na stałe w niepełnym wymiarze godzin (19\%), najmniejszą zaś osoby studiujące niepracujące (11\%). W kwestii zamieszkania przeważały osoby mieszkające $\mathrm{z}$ rodzicami (47\%), mniejszą grupę stanowiły badane mieszkające $\mathrm{z}$ partnerem $(23 \%)$ oraz $\mathrm{z}$ rówieśnikami (19\%), niemniejszą zaś mieszkające ze współmałżonkiem $(10 \%)$ oraz samotnie $(1 \%)$. Osób zamężnych lub posiadających stałego partnera było 50 (34\%), natomiast samotnych 22 (14\%). Pozostałe zadeklarowały związki na różnym poziomie intymności.

Wyznaczenie dolnej granicy wiekowej osób badanych na poziomie 22 . rok życia podyktowane było chęcią dotarcia do osób, które po ukończeniu szkoły średniej miały czas na przygotowanie się do podjęcia zadań rozwojowych typowych dla tego okresu, czy to poprzez odnalezienie się na rynku pracy, czy ukończenie studiów wyższych I stopnia lub poprzez podjęcie obu tych działań równocześnie. Górna granica wiekowa osób badanych, wyznaczona na 30. rok życia, wynika $z$ faktu iż, średnio w tym właśnie wieku (Boni, 2011; GUS, 2010; GUS, 2016) młodzi Polacy obydwu płci podejmująjuż wszystkie zadania typowe dla okresu wczesnej dorosłości.

\section{METODY}

W badaniu wykorzystano dwa narzędzia pomiarowe.

Skala Zadań Rozwojowych, własnego autorstwa, służy do badania sześciu zadań rozwojowych typowych dla okresu wczesnej dorosłości: zawarcie związku małżeńskiego/wybór partnera, podjęcie roli rodzica, podjęcie stałej pracy, samodzielne prowadzenie gospodarstwa domowego, znalezienie pokrewnej grupy społecznej oraz podjęcie obowiązków obywatelskich $^{1}$. Inspiracją dla tej skali była koncepcja Havighursta (1972) dostosowana do współczesnych warunków życia. Narzędzie umożliwia zbadanie siedmiu aspektów związanych z realizacją tychże zadań.

1. Pierwszy aspekt dotyczy samej obecności danego zadania rozwojowego $\mathrm{w}$ planach życiowych jednostki. Osoba badana odpowiada na pytanie, czy obecnie realizuje lub w przyszłości zamierza realizować dane zadanie rozwojowe. Osoby udzielające odpowiedzi negatywnej nie ustosunkowują się do pozostałych aspektów tego zadania.

2. Drugi aspekt dotyczy określenia, na jakim etapie realizacji danego zadania rozwojowego znajduje się jednostka. Osoba badana wybiera spośród wyróżnionej w narzędziu kafeterii odpowiedzi ten etap, który jest jej najbliższy. Odnosząc się do zadania rozwojowego, jakim jest zawarcie zwiazku matżeńskiego/wybór partnera, zaproponowano następujące etapy: $\square$ Jestem sama, jest mi z tym dobrze i nie szukam partnera; $\square$ Jestem sama - szukam partnera; $\square$ Co jakiś czas spotykam się z kimś, ale znajomości te nie są niczym poważnym; $\square$ Mam partnera, z którym spotykam się od pewnego 
czasu, ze znajomością tą jednak nie wiążę planów na przyszłość; $\square$ Mam partnera, z którym spotykam się od pewnego czasu - ze znajomością tą wiążę swoje plany na przyszłość; $\square$ Mam partnera, z którym mieszkam; $\square$ Mam żonę/męża. W przypadku zadania, jakim jest podjęcie stałej pracy, zaproponowano takie etapy, jak: $\square$ Nie pracuję i nie myślę jeszcze o podejmowaniu pracy zawodowej; $\square$ Nie pracuję, ale szukam pracy; $\square$ Pracuję dorywczo, ale zajęcia tego nie wiążę $\mathrm{z}$ moim dalszym rozwojem zawodowym; $\square$ Mam stała pracę, ale zajęcia tego nie wiążę z moim dalszym rozwojem zawodowym; $\square$ Pracuję dorywczo i zajęcie to wiąże $\mathrm{z}$ moim dalszym rozwojem zawodowym; $\square$ Mam stałą pracę i zajęcie to wiążę $\mathrm{z}$ moim dalszym rozwojem zawodowym.

3. Trzeci z badanych aspektów dotyczy stopnia przygotowania do realizacji danego zadania rozwojowego. Osoba badana ocenia na skali graficznej (10-centymetrowej) stopień przygotowania do pełnienia roli. Wynik po przeliczeniu na milimetry mieści się na skali od 0 do 100; (alfa-Cronbacha .48).

4. Czwarty badany aspekt dotyczy określenia subiektywnej ważności danego zadania rozwojowego. Osoba badana ocenia ważność na skali graficznej z opisanymi krańcami od „Zupełnie nieważne” do „Bardzo ważne”. Skalę tworzy odcinek o długości 10 centymetrów, tak że wynik po przeliczeniu na milimetry mieści się na skali od 0 do 100 (alfa-Cronbacha .63).

5. Piatym aspektem jest ocena tempa realizacji poszczególnych zadań rozwojowych względem grupy rówieśniczej, z użyciem 5-stopniowej skali kategorialnej, obejmującej takie możliwości, jak: „Dużo szybciej od większości moich rówieśników”, „Nieco szybciej od większości moich rówieśników”, „W podobnym czasie jak większość moich rówieśników”, „Nieco późnej niż większość moich rówieśników” oraz „Znacząco później niż większość moich rówieśników" (alfa-Cronbacha .48).

6. Kolejnym badanym aspektem jest rodzaj motywacji leżącej u podstaw realizacji po- szczególnych zadań rozwojowych. Osoba badana ocenia znaczenie czterech rodzajów motywacji pochodzących z taksonomii regulacji zachowania przyporządkowanej do wymiaru (kontinuum) autodeterminacji (Deci, Ryan, 1985): regulacja zewnętrzna (kary i nagrody) i introjekcja - składające się na motywację kontrolowaną oraz regulacja $\mathrm{z}$ identyfikacją i regulacja zintegrowana - składające się na motywację autonomiczną $^{2}$ (por. też Carr, 2009). Siła każdego typu regulacji jest szacowana za pomocą 4-stopniowej skali typu Likerta, która zaczynała się od punktu 0 - brak motywacji tego typu. Wskaźnikiem siły motywacji autonomicznej jest różnica punktowa między sumą punktów odnoszących się do regulacji zintegrowanej i zidentyfikowanej a sumą punktów odnoszących się do regulacji zewnętrznej i introjekcji. Ostateczny rezultat sytuuje się w granicach od -6 do 6 punktów. Im wyższy wynik, tym większe znaczenie dla realizacji danego zadania mają motywy charakterystyczne dla regulacji autonomicznej (alfa-Cronbacha .69).

7. Ostatnim badanym aspektem jest poczucie zadowolenia jednostki ze sposobu i tempa realizacji danego zadania rozwojowego. Osoba udziela odpowiedzi na skali graficznej z opisanymi krańcami od „Zupełnie niezadowolony” do „Bardzo zadowolony”. Skalę graficzną tworzy odcinek o długości 10 centymetrów, tak że wynik osoby badanej po przeliczeniu na milimetry mieści się na skali od 0 do 100 (alfa-Cronbacha .72). Opisane powyżej aspekty obliczane są $\mathrm{z}$ osobna dla każdego z zadań rozwojowych.

Kwestionariusz Procesów Tożsamościowych został stworzony na podstawie modelu formowania się tożsamości Luyckxa i współpracowników (2006), z pewnymi jego modyfikacjami (Słowińska, Oleszkowicz, 2015, 2016). Polegały one na wprowadzeniu dwóch procesów eksploracji ruminacyjnej (wszerz i w głąb), silniejszym zaznaczeniu refleksyjnego/pozytywnego charakter obu eksploracji adaptacyjnych, a także podkreśleniu tymczasowego charakteru podejmowanego zobowiązania (zaangażowania). 
Podstawowa wersja narzędzia składa się z 60 twierdzeń odnoszących się do procesów tożsamościowych, przebiegających w sześciu dziedzinach: zawód, rekreacja i światopogląd (sfera ideologiczno-zadaniowa) oraz związki intymne, przyjaźń i role płciowe (sfera interpersonalna). Osoba badana ustosunkowuje się do stwierdzeń z użyciem 4-stopniowej skali typu Likerta, od 1 (zdecydowanie mnie nie opisuje) do 4 (zdecydowanie mnie opisuje), np. Chętnie myślę o różnych zawodach, które mógtbym w przyszłości wykonywać (przykład eksploracji wszerz). W prezentowanych badaniach została wykorzystana skrócona wersja narzędzia, KPT-36, składająca się z 36 twierdzeń. Skrócona wersja kwestionariusza służy do badania tych samych procesów tożsamościowych, co wersja pierwotna, jest jednak znacznie wygodniejsza w użyciu dzięki wyraźnemu skróceniu czasu badania. Tak więc narzędzie umożliwia zbadanie procesów tożsamościowych w sześciu wymiarach: refleksyjnego poszukiwania szerokiego/ refleksyjnej eksploracji wszerz (alfa-Cronbacha .78), ruminacyjnego poszukiwania szerokiego/ ruminacyjnej eksploracji wszerz (.82), podejmowania zaangażowania/podejmowania zobowiązania (.70) (cykl formowania zobowiązania), refleksyjnego poszukiwania głębokiego/refleksyjnej eksploracji w głąb (.80), ruminacyjnego poszukiwania głębokiego/ruminacyjnej eksploracji w głąb (.82) oraz identyfikacji ze zobo- wiązaniem (.70) (cykl ewaluacji zobowiązania). Rzetelność testu została obliczona dla grupy 340 osób, uczniów szkół ponadgimnazjalnych i studentów. Wskaźniki dopasowania do modelu 6-czynnikowego wskazują na zadowalające, umiarkowane dopasowanie modelu do danych, $\chi^{2} / d f=2.97$; GFI $=.89$; $\mathrm{AGFI}=.86$; $\mathrm{RMSEA}=$ .035. Rozpiętość skal wyników surowych we wszystkich procesach tożsamościowych wynosi od 6 do 24 punktów. Im wyższy wynik, tym większe nasilenie danego procesu. Dla każdej osoby oblicza się sześć wskaźników.

\section{WYNIKI}

Analizę wyników rozpoczęłyśmy od sprawdzenia statystyk opisowych oraz rozkładów zmiennych odnoszących się do aktywności tożsamościowej, czyli procesów formowania się tożsamości (tabela 1).

Chociaż wskaźniki skośności i kurtozy nie osiągnęły wartości 1 lub (-1), aby zachować większą ostrożność wnioskowania, posłużono się początkowo testami nieparametrycznymi. Najpierw zostały przeanalizowane różnice między procesami reprezentującymi cykl formowania się zobowiązania i cykl ewaluacji zobowiązania (test Wilcoxona dla porównania prób zależnych). Istotnie wyższe wyniki $(p<.05)$ stwierdzono w zakresie refleksyjnego

Tabela 1. Statystyki opisowe, skośność i kurtoza dla procesów tożsamościowych

\begin{tabular}{|l|c|c|c|c|c|}
\hline \multicolumn{1}{|c|}{ Zmienne } & $\boldsymbol{M}$ & $\boldsymbol{M} \boldsymbol{S}$ & $\boldsymbol{S D}$ & Skośność & Kurtoza \\
\hline $\begin{array}{l}\text { Refleksyjne poszukiwanie } \\
\text { szerokie }\end{array}$ & 14.52 & 15 & 3.13 & -.12 & .09 \\
\hline $\begin{array}{l}\text { Ruminacyjne poszukiwanie } \\
\text { szerokie }\end{array}$ & 10.32 & 10 & 3.27 & 0.76 & 0.03 \\
\hline $\begin{array}{l}\text { Podejmowanie } \\
\text { zaangażowania }\end{array}$ & 17.43 & 18 & 3.41 & -.64 & .91 \\
\hline $\begin{array}{l}\text { Refleksyjne poszukiwanie } \\
\text { głębokie }\end{array}$ & 17.25 & 17 & 3.36 & -.55 & .77 \\
\hline $\begin{array}{l}\text { Ruminacyjne poszukiwanie } \\
\text { głębokie }\end{array}$ & 11.5 & 11 & 3.47 & .55 & -.13 \\
\hline $\begin{array}{l}\text { Identyfikacja ze } \\
\text { zobowiązaniem }\end{array}$ & 18.52 & 19 & 3.54 & -.67 & .60 \\
\hline
\end{tabular}


poszukiwania głębokiego $\mathrm{w}$ porównaniu $\mathrm{z}$ refleksyjnym poszukiwaniem szerokim, w zakresie ruminacyjnego poszukiwania głębokiego w porównaniu $z$ ruminacyjnym poszukiwaniem szerokim, jak też w zakresie identyfikacji ze zobowiązaniem $\mathrm{w}$ porównaniu $\mathrm{z}$ podejmowaniem zaangażowania. Tym samym w badanej grupie stwierdzono wyższe nasilenie procesów tożsamościowych z drugiego cyklu.

Aby poznać związki pomiędzy nasileniem poszczególnych procesów tożsamościowych a badanymi aspektami realizacji zadania rozwojowego zawarcie zwiazku matżeńskiego/ wybór partnera, przeprowadziłyśmy analizy korelacyjne (tabela 2). Otrzymane rezultaty wskazują na istnienie słabych bądź umiarkowanych, pozytywnych związków pomiędzy etapem realizacji zadania, stopniem spostrzeganego przygotowania do pełnej jego realizacji, poziomem ważności zadania, satysfakcją ze sposobu i tempa realizacji zadania oraz motywacją autonomiczną a identyfikacją ze zobowiązaniem. Tym samym prawie wszystkie badane aspekty realizacji zadania rozwojowego współwystępują z tym wymiarem tożsamości. Z kolei etap realizacji, ważność zadania i tempo realizacji $\mathrm{w}$ porównaniu $\mathrm{z}$ rówieśnikami wchodzą w ujemną zależność z refleksyjnym poszukiwaniem szerokim (im zadanie spostrzegane jest jako mniej ważne i będące na mniej zaawansowanym etapie realizacji, a tempo jako wolniejsze $\mathrm{w}$ porównaniu $\mathrm{z}$ rówieśnikami, tym bardziej jest nasilone poszukiwanie szerokie).

Stwierdzono też słabe (ale istotne) ujemne zależności pomiędzy etapem realizacji zadania, spostrzeganym przygotowaniem, motywacją autonomiczną i stopniem zadowolenia a eksploracją ruminacyjną wszerz (tabela 2). Oznacza to, że kobiety słabiej zaawansowane w realizacji tego zadania rozwojowego, mniej do niego przygotowane i w mniejszym stopniu wspierające się motywacją autonomiczną charakteryzują się większym niepokojem i niepewnością swoich poszukiwań tożsamościowych.

Uzyskane rezultaty w dużym stopniu potwierdzają hipotezy H1, H2, H3, H4, H5, H6 w odniesieniu do procesów identyfikacji ze zobowiązaniem, refleksyjnego poszukiwania szerokiego i eksploracji ruminacyjnej. Należy zaznaczyć, że nie potwierdziły się przewidywania odnośnie do procesu podejmowania zaangażowania. Proces ten nie wchodzi w żadne związki z większością badanych aspektów realizacji zadania zawarcie zwiqzku matżeńskiego/

Tabela 2. Procesy tożsamościowe a wybrane aspekty realizacji zadania - zawarcie związku małżeńskiego/ wybór partnera

\begin{tabular}{|c|c|c|c|c|c|c|c|}
\hline & $N$ & 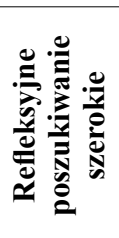 & 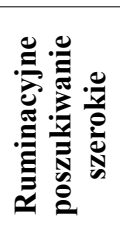 & 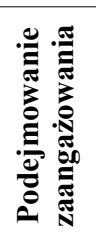 & 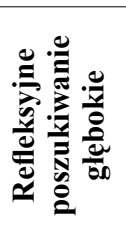 & 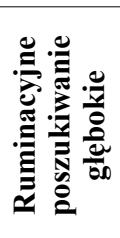 & 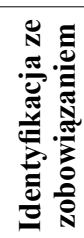 \\
\hline Etap realizacji & 142 & $-.31^{*}$ & $-.26 *$ & $-.16^{*}$ & $-.23 *$ & -.14 & $.18 *$ \\
\hline $\begin{array}{l}\text { Spostrzegane } \\
\text { przygotowanie }\end{array}$ & 142 & -.10 & $-.24 *$ & -.04 & -.01 & -.12 & $.34 *$ \\
\hline $\begin{array}{l}\text { Ważności } \\
\text { zadania }\end{array}$ & 142 & $-.22 *$ & -.14 & -.01 & .09 & -.09 & $.31 *$ \\
\hline $\begin{array}{l}\text { Motywacja } \\
\text { autonomiczna }\end{array}$ & 142 & -.13 & $-.20 *$ & .04 & .05 & $-.19 *$ & $.31 *$ \\
\hline Satysfakcja & 139 & -.15 & $-.28 *$ & -.06 & -.06 & $-.22 *$ & $.38 *$ \\
\hline Tempo & 142 & $.21 *$ & .02 & .13 & $.17 *$ & .01 & -.01 \\
\hline
\end{tabular}

${ }^{*} p<.05$ (test korelacji rho-Spearmana, $N=151$ ) 
wybór partnera, a w jednym wypadku związek jest istotny, ale z odwrotnym znakiem, niż przewidywano. Okazuje się, że im bardziej kobiety są zaawansowane w realizacji zadania, tym mniejsze $u$ nich nasilenie tymczasowego procesu podejmowania zobowiązania. Pozostałe procesy tożsamościowe: refleksyjne i ruminacyjne poszukiwanie głębokie, okazały się wiązać tylko z nielicznymi aspektami realizacji zadań rozwojowych (por. tabela 2). Charakter tych związków jest przeciwny niż w wypadku identyfikacji ze zobowiązaniem, co wskazuje na to, że im wolniejsze jest tempo i wcześniejszy etap realizacji zadania, tym silniejsze jest refleksyjne poszukiwanie głębokie, a ruminacyjne poszukiwanie głębokie pozostaje w związku z mniejszą motywacją autonomiczną i mniejszą satysfakcją z tempa i sposobu realizacji zadania.

Kolejne zadanie rozwojowe poddane analizie to podjęcie statej pracy. Aby poznać związki pomiędzy nasileniem poszczególnych procesów tożsamościowych a aspektami realizacji tego zadania, obliczono współczynniki korelacji rho-Spearmana (tabela 3 ).

Otrzymane rezultaty wskazują, iż istnieje pozytywny, ale słaby związek pomiędzy eta- pem realizacji zadania, spostrzeganym przygotowaniem do jego pełnej realizacji i satysfakcją $\mathrm{z}$ jego realizacji a procesem identyfikacji ze zobowiązaniem oraz występują słabe i umiarkowane związki ujemne tychże aspektów z eksploracją szeroką oraz eksploracją ruminacyjną szeroką i głęboką. Zaobserwowano także, że im mniej ważne jest zadanie, tym bardziej nasilone są procesy obu eksploracji ruminacyjnych. Z kolei nie wykazano związków między tempem realizacji i poziomem motywacji autonomicznej a żadnym procesem tożsamościowym (tabela 3). Nie stwierdzono związków między podjęciem zaangażowania (tymczasowym zobowiązaniem) i eksploracją w głąb a badanymi aspektami realizacji zadania. Tym samym nie potwierdziły się hipotezy H4 i H5. W dużym stopniu potwierdziły się hipotezy H1, H2 i H6, a tylko odnośnie do procesów eksploracji ruminacyjnej hipoteza $\mathrm{H} 3$.

W celu uzyskania informacji o najlepszych predyktorach identyfikacji ze zobowiązaniem, traktowanej jako najbardziej zaawansowanego wymiaru tożsamości, przeprowadzono krokową analizę regresji, oddzielnie dla każdego zadania. Zmiennymi niezależnymi były te aspekty reali-

Tabela 3. Procesy tożsamościowe a percepcja wybranych aspektów realizacja zadania - podjęcia aktywności zawodowej

\begin{tabular}{|c|c|c|c|c|c|c|c|}
\hline & $N$ & 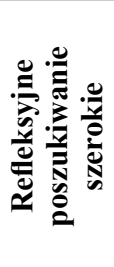 & 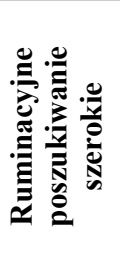 & 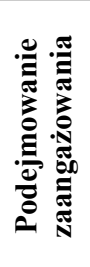 & 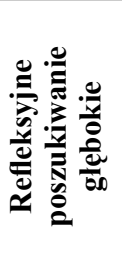 & 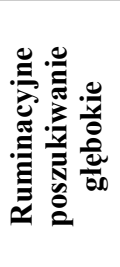 & 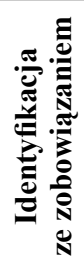 \\
\hline Etap realizacji & 144 & $-.20 *$ & $-.34 *$ & .01 & .13 & $-.22 *$ & $.19 *$ \\
\hline $\begin{array}{l}\text { Spostrzegane } \\
\text { przygotowanie }\end{array}$ & 143 & $-.24 *$ & $-.42 *$ & .07 & .09 & $-.29 *$ & $.31 *$ \\
\hline $\begin{array}{l}\text { Ważności } \\
\text { zadania }\end{array}$ & 143 & -.13 & $-.31 *$ & -.06 & .09 & $-.17 *$ & .09 \\
\hline $\begin{array}{l}\text { Motywacja } \\
\text { autonomiczna }\end{array}$ & 144 & -.03 & -.13 & .08 & .06 & -.01 & .09 \\
\hline Satysfakcja & 138 & $-.24 *$ & $-.34 *$ & -.04 & .04 & $-.21 *$ & $.27 *$ \\
\hline Tempo & 144 & .10 & .10 & .06 & .01 & .13 & .07 \\
\hline
\end{tabular}

${ }^{*} p<.05$ (test korelacji rho-Spearmana, $N=151$ ) 
zacji zadania, które korelowały istotnie $\mathrm{z}$ omawianym procesem (por. tabele 2 i 3). W przypadku zadania: zawarcie zwiazku matżeńskiego/ wybór matżonka zmienność procesu identyfikacji ze zobowiązaniem jest kontrolowana w 19\% przez wprowadzone do regresji aspekty zadania. Jednak istotnymi predyktorami są tylko: spostrzegany stopień przygotowania do pełnej realizacji tego zadania oraz motywacja autonomiczna. Im kobiety bardziej czują się przygotowane do podjęcia roli żony i im bardziej są motywowane czynnikami wewnętrznymi, tym bardziej jest u nich zaawansowany proces identyfikacji ze zobowiązaniem (tabela 4).

W wypadku drugiego zadania: podjęcie stałej pracy uzyskano wskaźnik na poziomie 9\% wyjaśnianej wariancji. Najistotniejszym predyktorem jest spostrzegany stopień przygotowania do pełnienia tej roli. Im bardziej kobiety czują się przygotowane do podjęcia stałej pracy zgodnej z planowaną ścieżką rozwoju zawodowego, tym bardziej mają zaawansowany proces identyfikacji ze zobowiązaniem (w różnych sferach życia).

\section{DYSKUSJA}

Przede wszystkim należy zauważyć, że w badanej grupie nasilenie procesów tożsamościowych składających się na drugi cykl (eksplora- cja głęboka, ruminacyjna eksploracja głęboka i identyfikacja ze zobowiązaniem) okazało się istotnie wyższe niż procesów pozostałych. Wynik ten jest zgodny z oczekiwaniami, albowiem osobami badanymi były kobiety reprezentujące okres wczesnej dorosłości. Zatem procesy tożsamościowe powinny być u nich na tyle zaawansowane, aby przybliżać jednostkę do etapu osiągnięcia dojrzałej tożsamości osobowej (Luyckx i in., 2008b; Słowińska, Oleszkowicz, 2015). Mniejsze nasilenie identyfikacji ze zobowiązaniem i większe nasilenie eksploracji wszerz w tym wieku może być spowodowane czynnikami osobowościowymi, np. lękiem (Brzezińska, Piotrowski, Garbarek-Sawicka, Karowska, Muszyńska, 2010).

Uzyskane zależności w dużej części są zgodne $\mathrm{z}$ oczekiwaniami. Przede wszystkim można zauważyć, że etap realizacji zadań rozwojowych, stopień spostrzeganego przygotowania oraz satysfakcja $z$ formy i tempa realizacji pozostają w pozytywnym związku z identyfikacją ze zobowiązaniem. Jest to zgodne z wynikami badań Luyckxa i in. (2008a) czy Piotrowskiego (2013). Jednocześnie kobiety bardziej zaangażowane w realizację tych dwóch zadań rozwojowych charakteryzują się mniejszym nasileniem refleksyjnej i ruminacyjnej eksploracji wszerz, co potwierdza ich przejście do drugiego cyklu kształtowania się tożsamości, cyklu ewaluacji zobowiązania.

Tabela 4. Regresja krokowa wsteczna dla zmiennej zależnej: identyfikacja ze zobowiązaniem. Zmienne niezależne: aspekty realizacja zadania rozwojowego skorelowane z IZ

\section{Zadanie: zawarcie związku małżeńskiego/wybór partnera}

$\mathrm{F}(4.130)=9.10 p<.00001 \mathrm{R}=.47 \mathrm{R}^{2}$ popr. $=.19$

\begin{tabular}{|l|c|c|c|c|}
\hline & Beta & Błąd standardowy & $t(129)$ & $P$ \\
\hline $\begin{array}{l}\text { Spostrzegane } \\
\text { przygotowanie }\end{array}$ & .30 & .09 & 3.41 & .0000 \\
\hline Motywacja wewnętrzna & .24 & .08 & 3.00 & .003 \\
\hline $\begin{array}{l}\text { Zadanie: podjęcie stałej pracy } \\
\mathrm{F}=(2.139)=7.93 p<.0005 \mathrm{R}=.32 \mathrm{R}^{2} \text { popr. }=.09\end{array}$ \\
\hline & Beta & Błąd standardowy & $t(135)$ & $P$ \\
\hline $\begin{array}{l}\text { Spostrzegane } \\
\text { przygotowanie }\end{array}$ & .29 & .11 & 2.86 & 0.004 \\
\hline
\end{tabular}


W wypadku zadania zawarcie zwiazku matżeńskiego/wybór partnera zaobserwowano dodatkowo pozytywne zależności między ważnością zadania i siłą motywacji autonomicznej (co oznacza przewagę regulacji opartej na identyfikacji i integracji z ja nad regulacją opartą na karach, nagrodach czy poczuciu winy) do podjęcia tej roli a identyfikacją ze zobowiązaniem. Im zadanie jest ważniejsze i motywowane poczuciem słuszności oraz zgodne z osobistym systemem wartości, tym większe nasilenie procesu identyfikacji, procesu odpowiedzialnego za podejmowanie długotrwałych zobowiązań. Warto przypomnieć, że wskaźnik identyfikacji ze zobowiązaniem (zob. Kwestionariusz Procesów Tożsamościowych) wyliczany jest na podstawie wyników uzyskanych w sześciu dziedzinach funkcjonowania: praca, światopogląd, czas wolny, intymne związki, przyjaciele i role płciowe. Zaobserwowany związek może oznaczać, że podjęcie lub znaczne zbliżenie się do roli żony (stałej partnerki) współwystępuje z domknięciem ważnych tożsamościowych decyzji w innych sferach życia. Jeśli przyjmiemy kierunek interpretacji taki, jaki proponuje Piotrowski (2013), oznaczałoby to, że konsekwencją zaawansowanej realizacji tego niezwykle odpowiedzialnego zadania, jakim jest wybór partnera życiowego, jest dookreślenie siebie również $\mathrm{w}$ innych istotnych zakresach funkcjonowania. Jednak naszym zdaniem kierunek tych zależności nie musi być tak jednoznaczny. Nie można wykluczyć, że to właśnie względna finalizacja procesu kształtowania tożsamości pozwala na podjęcie decyzji o realizacji zadań rozwojowych, szczególnie tych wymagających odpowiedzialności za innych, z których trudno się później wycofać (np. małżeństwo, rodzicielstwo).

W wypadku podejmowania stałej pracy, a więc zadania realizowanego relatywnie wcześniej, obserwujemy mniej zależności z identyfikacją ze zobowiązaniem. Szczególnie interesujący jest brak zależności między motywacją autonomiczną a identyfikacją ze zobowiązaniem. Prawdopodobnie podejmowanie pracy może być motywowane równie silnie czynnikami zewnętrznymi (np. brak środków do satysfakcjonującego życia), jak i wewnętrznymi (np. chęć samorozwoju). U kilku kobiet wystąpił ujemy wskaźnik motywacji, co świadczy o przewadze motywacji kontrolowanej nad autonomiczną. Wynik ten jest zgodny z rezultatami badań uzyskanymi przez Zuzannę Siwek (2017). Z badań tych, przeprowadzonych na grupie młodych dorosłych, wynika, że w odniesieniu do pracy zarobkowej doświadczają oni bardziej motywacji opartej na przymusie zewnętrznym lub wewnętrznym niż motywacji autonomicznej. Stąd podjęcie stałej pracy, jako jednego z pierwszych dla tego okresu życia zadań rozwojowych, może mieć mniejsze znaczenie dla procesu kształtowania się tożsamości. Otwarte pozostaje pytanie, czy tak się dzieje tylko w grupie kobiet, czy jest to raczej trend natury bardziej ogólnej. O ogólniejszym trendzie świadczą wyniki uzyskane przez Paulinę Plich (2017). Z jej badań wynika, że najmniejsze nasilenie procesu identyfikacji ze zobowiązaniem, zarówno u kobiet, jak i mężczyzn w wieku 20-27 lat, występuje właśnie w sferze zawodowej. Prawdopodobnie wynika to $\mathrm{z}$ faktu istnienia różnych form zatrudnienia i przekonania, że pracę można wiele razy zmieniać, zanim znajdzie się tę odpowiadającą własnym oczekiwaniom i ambicjom.

Ponadto można zauważyć, że im wyższy poziom zaangażowania (faktycznego, aksjologicznego, temporalnego, motywacyjnego i emocjonalnego) w realizację zadań rozwojowych, tym mniejsze nasilenie adaptacyjnej (refleksyjnej) eksploracji wszerz i eksploracji ruminacyjnej wszerz. A zatem zaangażowanie w zadania rozwojowe wiąże się z mniejszym niepokojem i mniejszym nasileniem poszukiwań charakterystycznych dla pierwszego cyklu, reprezentującego wstępną fazę formowania się tożsamości. W zasadzie wszystkie wymiary tożsamościowe (poza identyfikacją ze zobowiązaniem) wchodzą w ujemną zależność z różnymi aspektami realizacji zadań rozwojowych świadczącymi o ich poważnym traktowaniu (etap realizacji, poziom przygotowania, ważność, motywacja autonomiczna). Mniejsze znaczenie zadania rozwojowego ogólnie wyrażone w ocenie poszczególnych aspektów jego realizacji wiąże się z większym zaangażowaniem w procesy poszukiwania zarówno refleksyjnego, jak i ruminacyjnego. A to oznacza, że tylko wyższy poziom identyfikacji ze zobowiązaniem, de facto 
oznaczający decyzję w zakresie tego, kim chcę być i do czego dążę, jest wzmacniany lub sam wzmacnia realizację zadań rozwojowych (szczególnie widać to w odniesieniu do małżeństwa).

Warto również przyjrzeć się uzyskanym predyktorom identyfikacji ze zobowiązaniem, czyli najbardziej dojrzałego i zaawansowanego wymiaru tożsamości. Po stronie zadań rozwojowych jako predyktor powtarza się subiektywnie spostrzegany stopień przygotowania do pełnienia danej roli. Pozostaje otwarte pytanie, co osoba badana brała pod uwagę, oceniając swój stopień przygotowania. Może przygotowanie merytoryczne (np. posiadaną wiedzę, co może być szczególnie ważne w wypadku pracy zawodowej), może dojrzałość psychospołeczną zawierającą w sobie kompetencje interpersonalne, umiejętność radzenia sobie z problemami, poczucie odpowiedzialności za siebie i innych itp. A może gotowość motywacyjną związaną z przekonaniem, że już czas coś w swoim życiu zmienić. Wynik ten jest zgodny z rezultatami badań dotyczącymi dojrzałości psychospołecznej i procesów tożsamościowych (Piotrowski, 2013). Wydaje się zatem, że ten kierunek dalszych, pogłębionych badań jest nie tylko interesujący, ale i wskazany. Po części potwierdza to drugi uzyskany predyktor (motywacja autonomiczna), który okazał się istotny w przypadku zadania, jakim jest wybór matżonka/partnera. Uzyskane wyniki pokazują również, że zadania rozwojowe okresu wczesnej dorosłości są na tyle różnorodne, że warto je analizować oddzielnie, albowiem mogą mieć różne znaczenie i wchodzić w różne relacje z kształtującą się tożsamością.

Uzyskane wyniki badań pokazały, że sensowne jest analizowanie zadań rozwojowych poprzez ich różne wymiary i aspekty. Można również przewidywać, że związek między stopniem zaangażowania $\mathrm{w}$ realizację poszczególnych zadań a tożsamością jest bardziej złożony i zróżnicowany, niż wynika to $\mathrm{z}$ różnych dotychczasowych badań.

\section{PRZYPISY}

\footnotetext{
${ }^{1} \mathrm{~W}$ prezentowanych badaniach wykorzystano wyniki dotyczące dwóch zadań.

${ }^{2}$ Osoba badana odpowiadała na pytanie: Co skłania Cię do realizacji lub przygotowywania się do realizacji danego zadania (przykład opisu motywu identyfikacja: robię to, bo jestem przekonana, że to powinno się robić w moim wieku).
}

\section{BIBLIOGRAFIA}

Arnett J. (2000), Emerging Adulthood: A Theory of Development from the Late Teens through Twenties. American Psychologist, 55, 774-783.

Arnett J. (2004), Emerging Adulthood. A Winding Road from the Late Teens through the Twenties. New York: Oxford University Press.

Brzezińska A., Appelt K., Ziółkowska B., (2008), Psychologia rozwoju człowieka. W: J. Strelau, D. Doliński (red.), Psychologia. Podręcznik akademicki, 95-292. Gdańsk: GWP.

Brzezińska A., Kaczan R., Piotrowski K., Rękosiewicz, M. (2011), Odroczona dorosłość: fakt czy artefakt? Nauka, 4, 67-107.

Brzezińska A.I., Piotrowski K., Garbarek-Sawicka E., Karowska K., Muszyńska K. (2010), Wymiary tożsamościowe a ich podmiotowe i kontekstowe korelaty. Studia Psychologiczne, 49, 1, 81-93.

Boni M. (2011), Młodzi 2011. Warszawa: Kancelaria Prezesa Rady Ministrów.

Carr A. (2009), Psychologia pozytywna. Poznań: Zysk i S-ka.

Deci E.L., Ryan R.M. (1985), Intrinsic Motivation and Self-Determination in Human Behavior. New York: Plenum Press.

Danielsen L.M., Lorem A.E., Kroger J. (2000), The Impact of Social Context on the Identity-Formation Process of Norwegian Late Adolescents. Youth \& Society, 31, 3, 332-362.

Gurba E. (2011), Wczesna dorosłość. W: J. Trempała (red.), Psychologia rozwoju człowieka. Podręcznik akademicki, 287-311. Warszawa: PWN. 
GUS (2010). Ludność. Stan i struktura ludności oraz ruch naturalny w przekroju terytorialnym,www. start,gov.pl/gus/ludnose_PLK_HTML (dostęp: 22.04.2013).

GUS (2016), file:///C:/Users/Anna\%20M/Downloads/malzenstwa_i_dzietnosc_w_polsce.pdf (dostęp: 24.05.2017).

Havighurst R. (1972), Developmental Tasks and Education. New York: David McKay.

Infoplease, 2013. Median Age at First Marriage, 1890-2010, www.infoplease.com/ipa/A0005061.html (dostęp: 22.04.2013).

Liberska H. (2007), Współczesny obraz moratorium. W: B. Harwas- Napierała, H. Liberska (red.), Tożsamość a współczesność, 25-52. Poznań: Wydawnictwo Naukowe UAM.

Luyckx K., Goossens L., Soenens B. (2006), A Development Contextual Perspective on Identity Construction in Emerging Adulthood: Change Dynamics in Commitment Formation and Commitment Evolution. Developmental Psychology, 42, 366-380.

Luyckx K., Schwartz S., Goossens L., Pollock S. (2008a), Employment, Sense of Coherence, and Identity Formation. Journal of Adolescent Research, 23, 5, 566-591.

Luyckx K., Schwartz S.J. Berzonsky M., Soenens B. Vansteenkiste M. Smits I., Goossens L. (2008b), Capturing Ruminative Exploration: Extending the Four-dimensional Model of Identity Formation in Late Adolescence. Journal of Research in Personalisty, 42, 58-82.

Malina A. (2014), Wczesna dorosłość w cyklu życia człowieka. Współczesne problemy z realizacja zadań rozwojowych młodych dorostych. Bydgoszcz: Wydawnictwo UKW.

Marcia J. (1966), Development and Validation of Ego Identity Status. Journal of Personality and Social Psychology, 3, 551-558.

Marcia J. (1980), Identity in Adolescent. W: J. Adelson (ed.), Handbook of Adolescent Psychology, 159-187. New York: John Wiley.

Oleszkowicz A., Misztela A. (2015), How Do Young Poles Perceive Their Adulthood? Journal of Adolescent Research, 30, 6, 683-709.

Oleś M. (2010), Wymiary tożsamości a subiektywna jakość życia u młodzieży. Czasopismo Psychologiczne, 16, 1, 61-76.

Oleś P. (2011), Psychologia człowieka dorosłego: ciqgłość-zmiana-integracja. Warszawa: Wydawnictwo Naukowe PWN.

Piotrowski K., Brzezińska A.I. (2011), Identity, Self-Sufficiency and Disability in the Contexts of Educational and Vocational Activity. Polish Psychological Bulletin, 42, 3, 160-168.

Piotrowski K. (2013), Tożsamość osobista w okresie wkraczania w dorosłość. Wielichowo: TIPI.

Plich P. (2017), Poczucie własnej skuteczności a formowanie tożsamości w okresie stajacej się dorostości. Nieopublikowana praca magisterska. Wrocław: Uniwersytet Wrocławski, Instytut Psychologii.

Sikorska S. (2015), Polak opuszcza dom rodzinny przed 30-tkq, ale później niż przeciętny obywatel UE, http://www.pieniadz.pl/Polak,opuszcza,dom,rodzinny,przed,30tka,ale,pozniej,niz,przecietny,obywat el,UE,1-60185-1.html (dostęp: 24.05.2017).

Siwek Z. (2017), Autodeterminacja młodych dorostych w dqżeniach i codziennym funkcjonowaniu a poczucie dobrostanu psychofizycznego. Nieopublikowana praca doktorska. Wrocław: Uniwersytet Wrocławski, Instytut Psychologii.

Słowińska A., Oleszkowicz A. (2015), Kwestionariusz Procesów Tożsamościowych (KPT) - walidacja narzędzia. Studia Psychologiczne, 53, 3, 8-19.

Słowińska A., Oleszkowicz A. (2016), Modification of Luyckx et al.'s Integrated Process Oriented Model of Identity Formation. Polish Journal of Applied Psychology, 13, 4, 25-53.

Sugimura K., Mizokami S. (2012), Personal Identity in Japan. W: S.J. Schwartz (ed.), Identity Around The World. New Direction for Child and Adolescent Development, 123-143. San Francisco: Jossey-Bass, Wiley Periodicals.

Szlendak T. (2010), Socjologia rodziny: ewolucja, historia, zróżnicowanie. Warszawa: Wydawnictwo Naukowe PWN.

Turek B. (2013), Kobiety wyprowadzaja się od rodziców szybciej niż mężczyźni, http://serwisy.gazetaprawna. pl/nieruchomości (dostęp: 22.04.2013).

Zagórska W., Jelińska M., Surma M., Lipska A. (2012), Wydtużajqca się droga do dorostości. Warszawa: Wydawnictwo UKSW. 